IZA DP No. 7034

Migraine Headache and Labor Market Outcomes

Daniel I. Rees

Joseph J. Sabia

November 2012 


\title{
Migraine Headache and Labor Market Outcomes
}

\author{
Daniel I. Rees \\ University of Colorado Denver \\ and IZA \\ Joseph J. Sabia \\ San Diego State University
}

\section{Discussion Paper No. 7034 \\ November 2012}

\author{
IZA \\ P.O. Box 7240 \\ 53072 Bonn \\ Germany \\ Phone: +49-228-3894-0 \\ Fax: +49-228-3894-180 \\ E-mail: iza@iza.org
}

Any opinions expressed here are those of the author(s) and not those of IZA. Research published in this series may include views on policy, but the institute itself takes no institutional policy positions. The IZA research network is committed to the IZA Guiding Principles of Research Integrity.

The Institute for the Study of Labor (IZA) in Bonn is a local and virtual international research center and a place of communication between science, politics and business. IZA is an independent nonprofit organization supported by Deutsche Post Foundation. The center is associated with the University of Bonn and offers a stimulating research environment through its international network, workshops and conferences, data service, project support, research visits and doctoral program. IZA engages in (i) original and internationally competitive research in all fields of labor economics, (ii) development of policy concepts, and (iii) dissemination of research results and concepts to the interested public.

IZA Discussion Papers often represent preliminary work and are circulated to encourage discussion. Citation of such a paper should account for its provisional character. A revised version may be available directly from the author. 
IZA Discussion Paper No. 7034

November 2012

\section{ABSTRACT}

\section{Migraine Headache and Labor Market Outcomes}

While migraine headache can be physically debilitating, no study has attempted to estimate its effects on labor market outcomes. Using data drawn from the National Longitudinal Study of Adolescent Health, we estimate the effect of migraine headache on labor force participation, hours worked, and wages. We find that migraine headache is associated with a decrease in wages. However, there is little evidence that migraine headache leads to reductions in labor force participation or hours worked. We conclude that estimates of the cost of migraine headache to society should include its impact on wages.

JEL Classification: I10, J30

Keywords: migraine headache, wages, labor force participation, productivity

Corresponding author:

Daniel I. Rees

University of Colorado Denver

Department of Economics, CB 181

P.O. Box 173364

Denver, CO 80217-3364

USA

E-mail: Daniel.Rees@ucdenver.edu

\footnotetext{
* This research uses data from Add Health, a program project designed by J. Richard Udry, Peter S. Bearman, and Kathleen Mullan Harris, and funded by a grant P01-HD31921 from the National Institute of Child Health and Human Development, with cooperative funding from 17 other agencies. Special acknowledgment is due Ronald R. Rindfuss and Barbara Entwisle for assistance in the original design. Persons interested in obtaining data files from Add Health should contact Add Health, Carolina Population Center, 123 W. Franklin Street, Chapel Hill, NC 27516-2524 (http://www.cpc.unc.edu/addhealth/contract.html).
} 


\section{INTRODUCTION}

On the order of one out of every 10 American adults suffers from migraine headaches (Breslau and Rasmussen 2001). Despite the fact that migraine attacks are often accompanied by debilitating pain, sight impairment, and concentration lapses (Headache Classification Subcommittee of the International Headache Society 2004), and may lead to diminished human capital acquisition (Rees and Sabia 2010, Sabia and Rees 2011), no previous study has attempted to assess the impact of migraine headache on labor market outcomes such as wages. To the extent that migraine headaches reduce productivity, and therefore wages, previous estimates of their cost to society should be adjusted upwards.

Using ordinary least squares (OLS) and data from the National Longitudinal Study of Adolescent Health, we estimate that migraine headache is associated with a 4 to 6 percent reduction in wages controlling for occupation. However, medical researchers have found that both migraine and tension headache sufferers are more likely to exhibit neurotic tendencies than non-sufferers (Rasmussen 1992; Kentle 1997; Cao et al. 2002), raising the possibility that the OLS estimates are being driven by personality. In an effort to explore this hypothesis, we control for the respondent's score on a test of neuroticism as well as his or her score on a test of anxiety. Controlling for these scores has very little impact on the estimated relationship between migraines and wages.

Next, we pursue a two-stage estimation strategy, using mother’s migraine status as an instrument. This estimation strategy also produces evidence of a negative relationship between migraine headache and wages. Controlling for how much time the respondent spent with his or her parents and other parental investments has very little 
impact on this relationship, a result that adds to our confidence that it can be interpreted as causal. We conclude that migraine headache leads to a substantial reduction in wages, most likely due to its impact on productivity as opposed to occupation choice or hours worked.

\section{BACKGROUND}

Migraine headaches are triggered by a variety of stimuli, including stress, fatigue, lack of sleep, hunger, smoke, and bright lights (Kaniecki 2002). Approximately 20 percent of adult women in the United States report having had at least one migraine headache in the past year, while 5 to 6 percent of adult men in the United States report having suffered an attack in the past year (Stewart et al. 1992; Lipton et al. 2001; Lipton et al. 2007). Attacks last from 4 to 72 hours, involve moderate to severe pain, as well as nausea and sensitivity to bright light and loud noises (Headache Classification Subcommittee of the International Headache Society 2004). ${ }^{1}$

To our knowledge, no previous study has attempted to estimate the impact of migraine headache on wages or other employment outcomes such as hours or part-time status. However, when asked, migraineurs clearly indicate that they often experience reduced productivity while at work (Clarke et al.1996; Lipton et al. 2001; Waldie and Poulton 2002; Pradalier et al. 2004; Lipton et al. 2007). In fact, migraine sufferers in Western Europe report an average of 2-9 work days lost per year as a result of attacks (Berg 2004), and 25 percent of migraine sufferers in the United States report losing at

\footnotetext{
${ }^{1}$ According to the Headache Classification Subcommittee of the International Headache Society (2004, p. 150-151), moderate pain "inhibits, but does not wholly prevent usual activities," whereas severe pain "prevents all activities."
} 
least one day work in the past three months (Lipton et al. 2007). Based on figures such as these, it has been estimated that the indirect costs to society of migraine headache are much larger than the costs associated with treatment (Berg 2004). ${ }^{2}$

Using simple cross tabulation, medical researchers have found that migraine headache is negatively related to years of schooling and other measures of socioeconomic status (Breslau et al.1991; Stewart et al. 1992; Waldie et al. 2002; Waldie and Poulton. 2002; Lipton et al. 2007). Nevertheless, there is a perception among the general public that migraine sufferers tend to be overachievers, prone to feelings of anxiety and driven to succeed. ${ }^{3}$ This perception is perhaps fueled by the fact that stress is an important trigger of both migraine and tension headaches (Kaniecki 2002), and is buttressed by a growing number of medical studies documenting a link between migraine headache and neuroticism (Brandt et al. 1990; Merikangas et al. 1993; Breslau and Andreski 1995; Kentle 1997; Cao et al. 2002). ${ }^{4}$ Because there is some evidence that neuroticism can impact academic achievement (De Raad and Schouwenberg 1996; Laidra 2007), as well as evidence that personality type is related to earnings (Mueller and Plug 2006; Borghans

\footnotetext{
${ }^{2}$ After reviewing a number of studies using data from Western Europe, Berg (2004) concluded that the, "vast majority of the total costs, nearly $90 \%$, are due to indirect costs in the form of absenteeism and reduced effectiveness.” Direct medical costs were, on average, $€ 39$ per patient per year in Western Europe in (Berg 2004).

${ }^{3}$ Writing for the New York Times, Brody (1988) described migraines as occurring "with disproportionate frequency among high achievers who expect a lot from themselves and accomplish a lot.” The overachieving-migraineur hypothesis seems to be common even among medical professionals. In an interview with Vibrant Life, Dr. Seymour Diamond, the Executive Chairman of the National Headache Foundation, was asked if there "is such a thing as a migraine personality." He replied, "[m]any migraine patients are perfectionists. They tend to be intelligent, doers, and achievers." The full text of this interview is available at: http://findarticles.com/p/articles/mi_m0826/is_n4_v9/ai_14022967/?tag=content

${ }^{4}$ It should be noted, however, that the link between migraine and personality is still being investigated and debated. Nylander et al. (1996) found no evidence that migraine sufferers had different "temperaments or characters" than non-sufferers; Mattsson and Ekselius (2002) found no relationship between migraines and personality type among women ages 40-74; and Stronks et al. (1999) found that neither migraineurs nor subjects prone to tension headaches showed higher anxiety levels than members of a healthy control group when confronted with an arithmetic problem.
} 
et al. 2008), disentangling the effect of migraine headache from that of personality is potentially important.

\section{DATA AND MEASURES}

Our data are drawn from the National Longitudinal Study of Adolescent Health (Add Health), a nationally representative school-based survey conducted by the University of North Carolina at Chapell Hill, now made available to researchers by the University of Michigan. The Wave I in-home survey was administered to 20,745 seventh through twelfth graders between April and December of 1995 and includes oversampled of black students with college-educated parents as well as students of Chinese, Cuban, and Puerto Rican descent (see Harris et al 2008 for a detailed discussion of the Add Health sampling strategy.)

Three follow-up surveys to the baseline Add Health survey were conducted. The first was administered in 1996, one year after the baseline survey; the second was administered in 2001, when respondents were ages 18 to 26; and the third was conducted in 2007-2008, when respondents were ages 24 to 32 .

Our labor market outcomes are based on data from the third follow-up. After eliminating observations with missing information on labor force participation, migraine status at Wave I and the controls, our sample consists of 12,398 respondents. The sample reduced to 11,929 when we delete respondents with missing information on biological mother's migraine history and focus on migraine status at the third follow-up. It is reduced to 11,069 when we restrict this sample further to respondents who reported positive earnings in the previous year. 


\subsection{Measures}

A number of outcomes are considered. We created a dichotomous variable, Any Earnings, equal to one if the respondent reported positive personal earnings in the last year, and equal to zero if the respondent reported no earnings. In addition, we created the variables Hours Worked and Wages, both of which are logged in the regression analysis. ${ }^{5}$ Wages was based on the answers to the following question:

"Now think about your personal earnings. In [the previous year], how much income did you receive from personal earnings before taxes, that is, wages or salaries, including tips, bonuses, and overtime pay, and income from selfemployment?”

If a respondent replied "do not know” to the earnings question he or she was prompted with seven categories of earnings, the midpoints of each were used to code missing values. To calculate the wage, we divided the answer to the yearly earnings question by usual hours worked per week times fifty. ${ }^{6}$ The variable Wage is bottom-coded at \$2.13 per hour (the tipped Federal minimum wage in 2007) and top-coded at $\$ 500$ per hour. ${ }^{7}$ Approximately 5 percent of employed respondents in our sample earned less than $\$ 2.13$ per hour, and 0.04 percent earned more than $\$ 500$ per hour.

The independent variable of interest is Migraine. One parent, usually the mother, filled out a 40-minute questionnaire when the Wave I in-home survey was administered.

\footnotetext{
${ }^{5}$ Hours Worked was based on answers to the question, "[h]ow many hours a week (do/did) you usually work at this job?” This question was only asked if a respondent reported working at least 10 hours per week for their current employer.

${ }^{6}$ The Add Health survey does not ask respondents about usual weeks worked. See Sabia and Rees (forthcoming) for more information on how wages are calculated.

${ }^{7}$ Indicator variables are included on the right hand side of the wage equation for wages above the topcoded value and below the bottom-coded value.
} 
They were presented with a list of "health problems," and asked if their child, the respondent, was currently suffering from any of the problems on the list. Migraine is equal to 1 if the parent indicated that the respondent had migraine headaches, and is equal to 0 if the parent indicated that they did not. According to this measure, nearly 10 percent of male respondents in our sample, and 13 percent of the female respondents, suffered from migraine headache (Table 1).

The advantage to using Migraine is that it is measured when the respondent was in middle or high school, before they entered the labor market. The disadvantage is that distinguishing between migraine and tension headaches can often be difficult. Many migraine headaches are accompanied by tension headache symptoms and vice versa (Kaniecki 2002). If Add Health parents had trouble distinguishing between severe tension headaches and migraine headaches, then estimates based on the variable Migraine may understate the true effect of migraine headache on labor market outcomes.

An alternative measure of migraine headache is available at the third follow-up survey. Respondents were asked, "Has a doctor, nurse or other health care provider ever told you that you have or had migraine headaches?” Migraine Diagnosis is equal to one if a respondent answered this question in the affirmative, and is equal to zero otherwise. The advantage to this variable is that is it presumably a more accurate gauge of whether the respondent suffered from migraines at the time of the third follow-up survey. The disadvantage is that it is more likely to be correlated with job characteristics that could have had a direct impact on labor market outcomes measured at the third-follow-up. Consistent with research showing that women often experience their first migraine headache after adolescence (O’Brien et al. 1994), 20 percent of female 
respondents had been told by a health professional that they suffered from migraines by the third follow-up survey (Table 1). In contrast, only 13 percent of male respondents had been told by a health professional that they suffered from migraine headaches.

Regardless of which measure is used, respondents with zero earnings in the past year were more likely to be migraineurs. For instance, 22 percent of respondents with zero earnings had been told by a health professional that they suffered from migraine headaches, while 14 percent of respondents with positive earnings had been told by a health professional that they suffered from migraine headaches (Table 1). Conditional on having positive earnings in the past year, respondents who worked fewer than 40 hours per week were more likely to suffer from migraine headache (Table 1). Likewise, respondents who earned less than \$15 per hour were more likely to suffer from migraine headaches (Table 1).

\section{ESTIMATION}

\subsection{OLS estimation}

While the descriptive statistics reported in Table 1 are suggestive, previous research has shown that observables such as race and family income are important correlates of migraine status (Bigal et al. 2007). In an effort to account for the influence of observables such as these, we estimate the following equation using OLS:

$$
\mathrm{y}_{i}=\beta_{0}+\boldsymbol{\beta}^{\prime}{ }_{1} \mathbf{X}_{\mathbf{i}}+\boldsymbol{\beta}_{2} \text { Migraine }_{i}+\varepsilon_{i}
$$

where $\mathrm{y}_{i}$ represents one of the three dependent variables described above, and $\boldsymbol{X}_{\boldsymbol{i}}$ includes: the respondent's age, age-squared, job tenure, race, ethnicity, urbanicity, the 
respondent’s Peabody Picture Vocabulary Test (PPVT) score (a measure of cognitive ability $)^{8}$, educational attainment, current school enrollment, marital status, number of children, job tenure, occupation indicators, the educational attainment of the parent who answered the parental questionnaire, household income during adolescence, parents' marital status during adolescence, height, body mass index (BMI), and number of biological siblings, and whether the respondent had an older sibling.

In addition, we experiment with controlling for a broader set of (potentially endogenous) observables in an effort to capture individual characteristics that have been found to be associated with both migraine headache and labor market outcomes. These observables include: the Center for Epidemiological Studies Depression (CES-D) score and the Rosenberg Self-Esteem (RSE) score (Breslau et al.1991; Zwart et al. 2003), whether the respondent suffered from hypertension (Kelman and Rains 2005), whether the respondent reported usually being unable to get enough sleep (Scher et al. 2005), and indicators for number of times in the past month the respondents was drunk. This last control is included to account for the possibility that secondary headaches due to alcohol consumption were confused for migraine headaches.

As noted above, there is evidence that migraineurs score higher on tests designed to measure neuroticism than non-migraineurs (Brandt et al. 1990; Merikangas et al. 1993; Breslau and Andreski 1995; Kentle 1997; Cao et al. 2002). This is a potential threat to isolating the causal effect of migraine headache because previous studies have found that

\footnotetext{
${ }^{8}$ The PPVT measures verbal comprehension and vocabulary. The test is conducted by an interviewer who reads a word to a respondent and then has the respondent choose among four illustrations to determine the picture that best fits the word. The PPVT consists of 78 items (Harris and Thomas 2002). Adolescent Health respondents were administered 39 of these 78 items.
} 
diagnosis with a neurosis or an anxiety disorder can lead to sharply lower wages (Bartel and Taubman. 1986; Ettner et al. 1997; Marcotte and Wilcox-Gök. 2003). ${ }^{9}$

To explore whether neuroticism could be driving the estimated relationship between migraine headache and earnings, we take advantage of the fact Add Health contains a series of questions designed to measure neuroticism. At the third-follow-up, respondents were asked whether they "strongly agree” $(=1)$, "agree” $(=2)$, "neither agree nor disagree” (=3), “disagree” $(=4)$, or "strongly disagree” $(=5)$, with the each of the following statements:

1. I have frequent mood swings.

2. I am relaxed most of the time

3. I get upset easily

4. I seldom feel blue

Each respondent's neuroticism score was calculated by summing their responses (reverse coding their responses to the first and third statements).

In addition, we calculated an anxiety score for each respondent based on their answers to a similar set of questions. Specifically, at the third follow-up respondents were asked whether they "strongly agree” (=1), "agree” (=2), “neither agree nor disagree” (=3), "disagree" (=4), or "strongly disagree" $(=5)$ with the following statements:

1. I worry about things

2. I am not easily bothered by things

3. I get stressed out easily

4. I don't worry about things that have already happened

\footnotetext{
${ }^{9}$ Other papers have examined the relationship between broader measures of mental health and labor market earnings. See, for example, Frank and Gertler (1991) and Goldsmith et al. (1997), and Kessler et al. (2008).
} 
Each respondent's anxiety score was calculated by summing their responses (reversecoding their responses to the first and third statements).

\subsection{Instrumental variables estimation}

Stress is an important trigger of both migraine and tension headaches (Kaniecki 2002). Moreover, there is reason to believe that the labor market compensates workinduced stress (French and Dunlap 1998; Groot and Maassen van den Brink 1999; Glomb et al. 2004; Bryson et al. 2010). ${ }^{10}$ To the extent that work-induced stress—or any other difficult-to-observe job characteristic — is related to both the diagnosis of migraine headaches and our labor market outcomes, OLS estimates using Migraine Diagnosis will be biased, even controlling for personality and family background. ${ }^{11}$ One method of addressing this issue is through instrumental variables estimation.

There is strong evidence from the medical literature that migraine headache is inheritable. For instance, Russell and Olesen (1995) found that having a first-degree relative who suffered from migraine headache with aura was associated with a substantial increase in the likelihood of suffering from migraine headache with aura, and specific gene mutations have been linked to familial hemiplegic migraine (FHM) and sporadic hemiplegic migraine (SHM), rare and particularly severe subtypes of migraine headache (De Fuso et al. 2003; Vries et al. 2007; Anttila et al. 2008). ${ }^{12}$ Relying on this evidence,

\footnotetext{
${ }^{10}$ For instance, French and Dunlap (1998) found that workers who described their job as mentally stressful were paid 4 to 10 percent more than workers who did not describe their job as mentally stressful. See Verhofstadt et al. (2007) for evidence that job-related stress is not always compensated in the labor market.

${ }^{11}$ Whether health insurance is provided by the respondent's employer is another job characteristic that is potentially correlated with both being diagnosed with a migraine headache and wages.

12 Migraines with aura typically begin with visual disturbances such as flashes of light or flickering spots but otherwise they exhibit the same symptoms as migraine headache without aura, the most common type
} 
we estimate the following first-stage equation in an effort to identify exogenous variation in the respondent's migraine status:

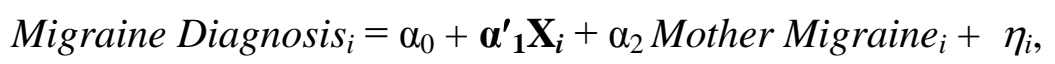

where Mother Migraine is equal to 1 if the respondent's biological mother was reported to have suffered from migraine headache, and is equal to 0 otherwise.

This estimation strategy will produce consistent second-stage estimates of $\beta_{2}$ provided that Mother Migraine is uncorrelated with the error term of equation (1), $\varepsilon_{i}$. However, it is possible that mothers who suffered from migraine headache had other inheritable health problems. It is also possible that mothers with migraine headache were unable to devote as much time and resources to their children's development as their nonmigraineur counterparts. To address these concerns, we experiment with augmenting the vector $\boldsymbol{X}_{\boldsymbol{i}}$ with indicators of parental health, whether the respondent's family moved to the neighborhood because of the quality of the school system, whether the parent who filled out the Add Health parental questionnaire was a member of the local parent teacher association, whether the respondent's mother worked outside of the home during his or her adolescence, whether the respondent and his or her parents made decisions together, the intensity of the parent's desire that their child go to college, and the degree to which the respondent's parents valued scholastic brilliance. ${ }^{13}$

of migraine headache (The Headache Classification Subcommittee of the International Headache Society 2004).

${ }^{13}$ Indicators of parental health were based on responses to the question, [h]ow is your general physical health? The possible responses were: "excellent," "very good," "good," "fair," and "poor.” A dichotomous measure of whether the respondent moved to the area because of school quality was based on responses to the question, "[y]ou live here because the schools here are better than they are in other neighborhoods?" Parental aspirations with regard to their children's scholastic performance were based on responses to the 


\section{THE RESULTS}

Our main results are presented in Tables 2-10. The focus is on estimates of $\beta_{2}$; estimates of the other parameters are available upon request. Standard errors are corrected for clustering at the school level, as per the Add Health research design.

\subsection{OLS Estimates}

Table 2 reports OLS estimates of the effect of migraine status on labor force participation (as measured by Any Earnings), and the natural log of current hours. The first three columns show estimates of estimates of $\beta_{2}$ for the pooled sample, which is composed of both male and female respondents. The remaining columns show OLS estimates of $\beta_{2}$ by gender.

Without any controls on the right-hand side of the estimating equation, there is evidence of a negative relationship between migraine headache and the probability labor force participation. For instance, migraine headache is associated with a 0.022 decrease in the probability of participation for the pooled sample. However, when the demographic and family background controls are added, the estimates of $\beta_{2}$ become much smaller and lose statistical significance.

question, “[i]f \{NAME could be one of the following in high school, which would be most important to you?” Possible responses were, “a brilliant student,” "a leader in school activities,” "an athletic star," "the most popular,” and “(He/she) has already graduated from high school.” Parental expectations of college attendance were based on responses to the question, "[h]ow disappointed would you be if $\{$ NAME $\}$ did not graduate from college?” Possible responses were: "very disappointed,” "somewhat disappointed,” and “not disappointed.” Finally, we assessed involvement in official school organizations using responses to the following question, "[p]lease tell me whether you are a member of any of the following: Parent/teacher organization.” Parental employment was measured by parental responses to the question, "Do you work outside the home?” The quality of the parental-child relationship was measured by the parent's responses on the frequency with which the reported the following: "You get along well with him/her" and "You make decisions about life together with him/her." Responses to each item were "always,” "often,” "seldom,” "sometimes," and "never." 
When Any Earnings is replaced with the log of hours worked, a similar pattern of results emerges. In the pooled sample, migraine headache is associated with a 2.3 percent decrease in hours worked $\left(\mathrm{e}^{-0.023}-1=0.023\right)$ without controls on the right-hand side of the estimating equation; when the demographic and family background controls are added, this estimate is reduced in absolute magnitude and becomes statistically insignificant.

Even with these controls there is a negative and statistically significant relationship between migraine headache and hours worked among male respondents. Specifically, migraine headache is associated with a 1.9 percent decrease in the number of hours worked by males. However, when we condition on years of schooling, the respondent's PPVT score, and whether the respondent was enrolled in school at the third follow-up survey, this estimate becomes statistically insignificant at conventional levels. Conditioning on these variables is important because there is evidence that migraineurs are less likely to graduate high school and less likely to attend college than nonmigraineurs (Rees and Sabia 2011; Sabia and Rees 2011).

Turning our attention to hourly earnings, the results in Table 3 are consistent with the hypothesis that migraineurs are less productive in the workplace than nonmigraineurs. Controlling for the basic set of demographic and family background characteristics, migraine headache is associated with an 8.3 percent decrease in the wages of male respondents, and a 5.5 percent decrease in the wages of female respondents. The estimated relationship between migraine headache and the log of wages is reduced, but is not eliminated, when we control for years of schooling, the respondent's PPVT score, and whether the respondent was enrolled in school at the third follow-up survey. 
Specifically, migraine headache is associated with a 6.0 percent decrease in the wages of male respondents, and a 4.8 percent decrease in the wages of female respondents.

In the last column of Table 3 we add a set of indicators corresponding to the respondent's two-digit SIC occupational code to the right-hand side of the estimating equation. Controlling for occupation has very little impact on our estimates. Migraine headache is still associated with a 6.2 percent decrease in the wages of male respondents, and a 4.1 percent decrease in the wages of female respondents. This pattern of results suggests that migraine headache does not reduce wages through its effect on occupational choice.

Table 4 explores the effects of Migraine Diagnosis on labor force participation and hours worked. Controlling for educational attainment, personal characteristics and family background, female respondents who were, by the third follow-up, told by a health professional that they suffered from migraine headaches were 2.0 percentage points less likely to participate in the labor market. Although negative, the estimated relationship between Migraine Diagnosis and male labor market participation is never statistically significant. There is little evidence that hours of work are related to migraine status for respondents of either gender.

Although being diagnosed with migraines does not appear to have a substantial impact on either labor force participation or hours of work conditional on labor force participation, there is evidence that it is negatively related to wages. Estimates of the relationship between Migraine Diagnosis and wages are presented in Table 5. They are consistently negative, but are slightly smaller than the estimates of the relationship between Migraine and wages presented in Table 3. Controlling for occupation and 
educational attainment, being diagnosed with migraines is associated with a 5.0 percent decrease in the wages of male respondents, and a 4.5 percent decrease in the wages of female respondents. Both of these estimates are significant at the 0.10 level.

Migraine headaches can be triggered by difficult-to-observe environmental factors such as such as noise, weather, or florescent lighting (Kaniecki 2002). ${ }^{14}$ In Table 6, we test whether our estimates of $\beta_{2}$ are sensitive to adding school and grade fixed effects to the right-hand side of the estimation equation. ${ }^{15}$ In addition, we control for comorbidities such as depression, sleep deprivation, hypertension and indicators for number of times in the past month the respondents was drunk. The estimates continue to show evidence of a negative relationship between migraine headache and wages, albeit reduced in magnitude when the sample is restricted to females. ${ }^{16}$

Although the results discussed thus far are consistent with the hypothesis that migraine headache lowers workplace productivity, we have not ruled out the possibility that they are driven by personality traits such as neuroticism. In Table 7, we add controls for the neuroticism and anxiety. The results are not consistent with the hypothesis that migraineurs earn less than non-migraineurs because of their personalities. After controlling for the respondent's neuroticism and anxiety scores, we find that migraine

\footnotetext{
${ }^{14}$ There is also evidence that community characteristics could be related to the incidence of migraine headache. For instance, Bigal et al. (2007) and Lipton et al. (2007) found that regional population density was related to the likelihood of migraine headache.

${ }^{15}$ The grade effects are five indicators based on the grade of the respondent at baseline (Wave I).

${ }^{16}$ Appendix Table 1 shows the robustness of the estimated association between Migraine Diagnosis and labor market outcomes to these additional controls. The findings are consistent with those reported in Table 6.
} 
headache is associated with a 6.1 percent decrease in male wages and a 3.9 percent decrease in female wages. ${ }^{17}$

\subsection{SLS Estimates}

OLS estimates of the relationship between Migraine and labor market outcomes could be misleading if parents misdiagnosed tension headaches as migraine headaches. Although Migraine Diagnosis is probably a more accurate gauge of the respondent's migraine status at the third follow-up, if work-induced stress is related to diagnosis by a health professional, then OLS estimates of the relationship between Migraine Diagnosis and labor market outcomes are also potentially misleading. In order to address these issues, we turn to instrumental variables estimation.

Estimates of the relationship between mother's migraine status and whether the respondent was diagnosed with a migraine headache by a health professional are presented in Table 8. Consistent with evidence from the medical literature, we find that having a biological mother who suffered from migraine headaches is associated with a statistically significant 4.7 to 4.8 percentage-point increase in the probability that male residents suffered from migraine headache, and an 8.5 to 9.0 percentage-point increase in the probability that female respondents suffered from migraine headache. The F-statistics in the first-stage easily meet the Staiger and Stock (1997) standard, with values ranging from 20.0 to 57.0 .

Table 9 presents 2-stage least squares (2SLS) estimates of the relationship between Migraine Diagnosis and the labor market outcomes under study. Again, there is

\footnotetext{
${ }^{17}$ Appendix Table 2 shows the sensitivity of the estimated association between Migraine Diagnosis and wages to controls for the neuroticism and anxiety. The results are consistent with those reported in Table 7.
} 
little evidence that being diagnosed with a migraine headache adversely affects labor force participation or hours worked. However, the 2SLS estimates of the relationship between Migraine Diagnosis and wages are substantially more negative than the OLS estimates using Migraine, suggesting that parents may have confused migraine headaches with severe tension headaches. They are also more negative than the OLS estimates using Migraine Diagnosis, consistent with the hypothesis that work-induced stress is compensated in the labor market but leads to diagnosis with migraine headaches.

Without controls for parental health and involvement, being diagnosed with a migraine headache is associated with a 27.4 percent decrease in wages for the pooled sample. When the sample is restricted to males, it is associated with a (statistically insignificant) 30.1 percent decrease in wages, and when the sample is restricted to females it is associated with a 27.1 percent decrease in wages. However, the 2SLS estimates are imprecise. In fact, the standard errors are roughly an order of magnitude larger than the standard errors obtained using OLS. As a consequence, we cannot reject the hypothesis that the OLS and 2SLS estimates are equal in magnitude.

If parental health and involvement in school-related activities are associated with mother's migraine status and the respondent's labor market outcomes, then controlling for them is potentially important. In order to explore this possibility, we experiment with adding indicators of parental health, whether the respondent's family moved to the neighborhood because of the quality of the school system, whether the parent who filled out the Add Health parental questionnaire was a member of the local parent teacher association, the intensity of the parent's desire that their child go to college, and the degree to which the respondent's parents valued scholastic brilliance. The addition of 
these controls to the estimating equation only slightly diminishes the magnitude of the 2SLS estimates, suggesting that mother’s migraine status does not impact wages through these channels.

Finally, we experimented with using an additional instrument for Migraine Diagnosis: the respondent's migraine status at Wave I, Migraine. As noted above, the variable Migraine is based on answers to the parental questionnaire. Parents may have confused tension and migraine headaches, but the parental questionnaire was administered when respondents were in middle or high school. Therefore Migraine, although probably measured with error, could not have been influenced by work-induced stress.

When both Migraine and mother's migraine status are used as instruments, the second-stage estimates, although still imprecise, are smaller than those reported in Table 9. Being diagnosed with a migraine headache is associated with a 16.9 percent decrease in wages for the pooled sample. When the sample is restricted to males, it is associated with a 22 percent decrease in wages, and when the sample is restricted to females it is associated with a (statistically insignificant) 14 percent decrease in wages. These results are available upon request.

\section{CONCLUSION}

Using data drawn from the National Longitudinal Study of Adolescent Health, this study is the first to investigate the effect of migraine headache on labor market outcomes. We pursue a range of empirical strategies in order to address potential endogeneity issues. Across these strategies, our results provide consistent evidence that 
migraine headache is associated with sharp decreases in wages of young adults. There is little evidence that migraine headache impacts labor force participation or hours worked conditional on participating in the labor market.

Controlling for occupation and educational attainment, ordinary least squares estimates suggest that migraine headache is associated with a 5-6 percent decrease in the wages of males, and a 3-4 percent decrease in the wages of females. Using instrumental variables estimation to account for the influence of job-related stress on whether the respondent had been diagnosed with a migraine headache produces evidence of even larger reductions in workplace productivity, although the estimated relationship between migraine status and males wages is not statistically significant and we cannot reject the hypothesis that the OLS and 2SLS estimates are equal in magnitude.

Recently, a number of new prescription migraine medications from a class of drugs called triptans have come onto the market and are now in wide use. Although no medication is 100 percent effective, the introduction of these more effective drugs may have increased the workplace productivity of migraine sufferers. To the extent that this is the case, our estimates should be viewed as lower-bounds. It should be noted, however, that many sufferers delay taking prescription medications when they sense a headache coming on, and some choose to avoid taking them altogether. For instance, one study found that approximately two thirds of migraineurs delayed or avoided taking prescription drugs due to concerns about their side effects, which include difficulty concentrating, dizziness, nausea, and sleepiness (Gallagher and Kunkel 2003).

To put the magnitude of our estimates in perspective, it is useful to compare them to estimated effects of other health conditions on wages. For instance, Currie and Hyson 
(1999) found that low birth weight is associated with a 2-4 percent decrease in wages;

Fletcher (2009) found that adolescent depression is associated with a 15 percent reduction in labor market earnings; and Fletcher (2010) found that ADHD is associated with a 33 percent reduction in earnings. Thus, migraine headaches do not appear to be as debilitating as ADHD, but their effects on productivity are certainly as large as weighing less than 2,500 grams at birth, the cutoff for low birth weight typically used in the medical profession.

Approximately 10 percent of American adults suffer from migraine headaches (Breslau and Rasmussen 2001). Yet, no previous study has examined the effects of this debilitating condition on labor market outcomes such as hours and wages. Our results suggest that migraine sufferers are less productive than their counterparts who do not struggle with the pain, sight impairment, and concentration lapses that come with migraines. Future estimates of the cost of migraine headache to society should be adjusted upwards, perhaps substantially. 


\section{REFERENCES}

Anttila, Verneri, Dale R. Nyholt, Mikko Kallela, Ville Artto, Salli Vepsalainen, Eveliina Jakkula, Annika Wennerstro, Paivi Tikka-Kleemola, Mari A. Kaunisto, Eija Hamalainen, Elisabeth Widen, Joseph Terwilliger, Kathleen Merikangas, Grant W. Montgomery, Nicholas G. Martin, Mark Daly, Jaakko Kaprio, Leena Peltonen, Markus Farkkila, Maija Wessman, and Aarno Palotie. 2008. "Consistently “Replicating Locus Linked to Migraine on 10q22-q23.” American Journal of Human Genetics, Vol. 82, No. 5, pp. 1051-1063.

Bartel, Ann and Paul Taubman. 1986. "Some Economic and Demographic Consequences of Mental Illness.” Journal of Labor Economics, Vol. 4, pp. 243-256.

Berg, Jenny. 2004. “Economic Evidence in Migraine and Other Headaches: A Review.” European Journal of Health Economics, Vol. 5, Supplement 1, pp. S43-S54.

Bigal, E.M., R. B. Lipton, P. Winner, M. L. Reed, S. Diamond, and W. F. Stewart. 2007. "Migraine in Adolescents: Association with Socioeconomic Status and Family History." Neurology, Vol. 69, No. 1, pp. 16-25.

Borghans, Lex, Angela Lee Duckworth, James J. Heckman, Bas ter Weel. 2008. “The Economics and Psychology of Personality Traits.” IZA Discussion Paper No. 3333, Bonn Germany.

Brandt, J., D. Celentano, W. Stewart, M. Linet, and M.F. Folstein. 1990. "Personality and Emotional Disorder in a Community Sample of Migraine Headache Sufferers.” American Journal of Psychiatry, Vol. 147, No 3, pp. 303-308.

Breslau Naomi, Glen C. Davis, and Patricia Andreski. 1991. "Migraine, Psychiatric Disorders, and Suicide Attempts: An Epidemiologic Study of Young Adults.” Psychiatry Research, Vol. 37, pp. 11-23.

Breslau, Naomi and Patricia Andreski. 1995. "Migraine, Personality, and Psychiatric Comorbidity.” Headache, Vol. 35, No. 7, pp. 382-386.

Breslau, Naomi and Birthe K. Rasmussen. 2001. "The Impact of Migraine Epidemiology, Risk Factors, and Co-Morbidities.” Neurology, Vol. 56, Supplement 1, pp. S4-S12.

Brody, Jane E. 1988. “Personal Health.” New York Times, Thursday October 13. Available at: http://www.nytimes.com/1988/10/13/us/health-personal-health.html

Bryson, Alex, Erling Barth, and Harald Dale-Olsen. 2010. "Do Higher Wages Come at a price?”NIESR Discussion Paper No. 371. Available at:

http://www.niesr.ac.uk/pdf/231110_173447.pdf 
Cao, Ming, Shiyang Zhang, Keyong Wang, Yehan Wang, and Wei Wang. 2002. "Personality Traits in Migraine and Tension-Type Headaches: A Five-Factor Model Study.” Psychopathology, Vol. 35, No.4, pp. 254-258.

Clarke, C.E., L. MacMillan, S. Sondhi, and N.E. Wells. 1996. "Economic and Social Impact of Migraine.” Q J M, Vol. 89, No. 1, pp. 77-84.

Currie, Janet, and Rosemary Hyson (1999). "Is the Impact of Health Shocks Cushioned by Socioeconomic Status?: The Case of Birth Weight.” American Economic Review, 89 No. 2, pp. 245-250.

De Fusco, Maurizio, Roberto Marconi, Laura Silvestri, Luigia Atorino, Luca Rampoldi, Letterio Morgante, Andrea Ballabio, Paolo Aridon, and Giorgio Casari. 2003.

"Haploinsufficiency of ATP1A2 Encoding the Na+/K+ Pump $\alpha^{2}$ Subunit Associated with Familial Hemiplegic Migraine Type 2.” Nature Genetics, Vol. 333, No. 2, pp. 192-196.

De Raad, Boele and Henri C. Schouwenburg. 1996. "Personality in Learning and Education: A Review” European Journal of Personality, Vol. 10, No. 5, pp. 303-336.

Ettner, Susan L., Richard G. Frank, and Ronald C. Kessler. 1997. "The Impact of Psychiatric Disorders on Labor Market Outcomes.” Industrial and Labor Relations Review, Vol. 51, No. 1, pp. 64-81.

Fletcher, Jason M. 2009. “Adolescent Depression and Adult Labor Market Outcome.” Yale University Working Paper.

Fletcher, Jason M. 2010. "The Effects of Childhood ADHD on Adult Labor Market Outcomes.” Yale University Working Paper.

Frank Richard and Paul Gertler. 1991. "An Assessment of Measurement Error Bias for Estimating the Effect of Mental Distress on Income” Journal of Human Resources, Vol. 26, No. 1, pp. 154-164.

French, Michael T. and Laura J. Dunlap. 1998. "Compensating Wage Differentials for Job Stress.” Applied Economics, Vol. 30, No. 8, pp. 1067-1075.

Gallagher, R. Michael and Robert Kunkel. 2003. "Migraine Medication Attributes Important for Patient Compliance: Concerns about Side Effects May Delay Treatment.” Headache: The Journal of Head and Face Pain, Vol. 43, No.1, pp. 36-43.

Glomb, Theresa M. John D. Kammeyer-Mueller, and Maria Rotundo. 2004. "Emotional Labor Demands and Compensating Wage Differentials.” Journal of Applied Psychology, Vol. 89, No. 4, 700-714. 
Goldsmith, Arthur H., Jonathan R.Veum, and William Darity. 1997. “The Impact of Psychological and Human Capital on Wages.” Economic Inquiry, Vol. 35, No. 4, pp. 815-829.

Groot, Wim and Henriette Maassen van den Brink. 1999. “The Price of Stress.” Journal of Economic Psychology, Vol. 20, No. 1, pp. 83-103.

Harris, Kathleen Mullan, Carolyn Tucker Halpern, Pamela Entzel, Joyce Tabor, Peter S. Bearman, and J. Richard Udry. 2008. The National Longitudinal Study of Adolescent Health: Research Design [WWW document]. URL: http://www.cpc.unc.edu/projects/addhealth/design

Harris, David R. and Justin L. Thomas. 2002. “The Educational Costs of Being Multiracial: Evidence from a National Survey of Adolescents,” Research Report No. 02-521, Population Studies Center at the Institute of Social Research, University of Michigan.

Headache Classification Subcommittee of the International Headache Society. 2004. "International Classification of Headache Disorders, 2nd edition.” Cephalalgia, Vol. 24, No S1, pp. 8-160.

Kaniecki, Robert G. 2002. "Migraine and Tension-Type Headache An Assessment of Challenges in Diagnosis.” Neurology, Vol. 58, No. 9, pp. S15-S20.

Kelman, Leslie and Jeanetta C. Rains. 2005. "Headache and Sleep: Examination of Sleep Patterns and Complaints in a Large Clinical Sample of Migraineurs.” Headache: The Journal of Head and Face Pain, Vol. 45 No. 7, pp. 904-910.

Kentle, Robert L. 1997. "Elements of Neuroticism in Relation to Headache Symptomatology.” Psychological Reports, Vol. 80, No. 1, pp. 227-235.

Kessler, Ronald C., Steven Heeringa, Matthew D. Lakoma, Maria Petukhova, Agnes E. Rupp, Michael Schoenbaum, Philip S Wang, and Alan M. Zaslavsky. 2008. "Individual and Societal Effects of Mental Disorders on Earnings in the United States: Results from the National Comorbidity Survey Replication.” American Journal of Psychiatry, Vol. 165, No. 6, pp. 703-711.

Laidra, Kaia, Helle Pullmann, and Juri Allik. 2007. "Personality and Intelligence as Predictors of Academic Achievement: A Cross-Sectional Study from Elementary to Secondary School.” Personality and Individual Differences, Vol. 42, pp. 441-451.

Lipton, Richard B., Walter F. Stewart , Seymour Diamond, Merle L. Diamond, Michael L. Reed. 2001. "Prevalence and Burden of Migraine in the United States: Data from the American Migraine Study II.” Headache, Vol. 41, No. 7, pp. 646-57. 
Lipton, R. B, M. E. Bigal, M. Diamond, F. Freitag, M. L. Reed, and W. F. Stewart. 2007. "Migraine Prevalence, Disease Burden, and the Need for Preventive Therapy." Neurology, Vol. 68, No. 5, pp. 343-349.

Marcotte, Dave E. and Virginia Wilcox-Gök. 2003. “Estimating Earnings Losses due to Mental Illness: A Quantile Regression Approach.” The Journal of Mental Health Policy and Economics, Vol. 6, No. 3, pp. 123-134.

Mattsson, P. and L. Ekselius. 2002. "Migraine, Major Depression, Panic Disorder, and Personality Traits in Women Aged 40-74 Years: A Population-Based Study.” Cephalalgia, Vol. 22, No. 7, pp. 543-551.

Merikangas, Kathleen R., Denise E. Stevens, and Jules Angst. 1993. "Headache and Personality: Results of a Community Sample of Young Adults.” Journal of Psychiatric Research, Vol. 27, No. 2, pp. 187-196.

Mueller, Gerrit and Erik Plug. 2006. "Estimating the Effect of Personality on Male and Female Earnings.” Industrial and Labor Relations Review, Vol. 60, No. 1, pp. 3-22. Nylander, Per-Olof, Paul Schlette, Sven Brändström, Marita Nilsson, Thomas Forsgren, Lars Forsgren, and Rolf Adolfsson. 1996. "Migraine: Temperament and Character. Journal of Psychiatric Research, Vol. 30, pp. 359-368.

O’Brien, Bernie, Ron Goeree, and David Streiner. 1994. "Prevalence of Migraine Headache in Canada: A Population-Based Survey.” International Journal of Epidemiology, Vol. 23, No. 5, pp. 1020-1026.

Pradalier, Andre, Jean-Paul Auray, Abdelkader El Hasnaoui, Kazem Alzahouri, JeanFrancois Dartigues, Gerard Duru, Patrick Henry, Michel Lanteri-Minet, Christian Lucas, Guy Chazot, and Anne-Francois Gaudin. 2004. "Economic Impact of Migraine and Other Episodic Headaches in France: Data from the GRIM2000 Study.” Pharmacoeconomics, Vol. 22, No. 15, pp. 985-999.

Rasmussen, Birthe K. 1992. "Migraine and Tension-Type Headache in a General Population: Psychosocial Factors.” International Journal of Epidemiology, Vol. 21, No. 6, pp.1138-1143.

Rees, Daniel I. and Joseph J. Sabia. 2011. "The Effect of Migraine Headache on Educational Attainment.” The Journal of Human Resources, Vol. 46, No. 2, pp. 317-332.

Russell, Michael B. and Jes Olesen. 1995. "Increased Familial Risk and Evidence of Genetic Factor in Migraine.” British Medical Journal, Vol. 311, No. 7004, pp. 541-544.

Sabia, Joseph J. and Daniel I. Rees. 2011. "Individual Heterogeneity and Reverse Causality in the Relationship between Migraine Headache and Educational Attainment." Economics of Education Review, Vol. 30, No. 5, pp. 913-923. 
Scher, A. I., G. M. Terwindt, S.J. Picavet, M.M. Verschuren, M. D. Ferrari, and L. J. Launer. 2005. "Cardiovascular Risk Factors and Migraine: The GEM Population-Based Study.” Neurology, Vol. 64, No. 4, pp. 614-620.

Stewart, Walter F. Richard B. Lipton, David D. Celentano, and Michael L. Reed. 1992. "Prevalence of Migraine Headache in the United States. Relation to Age, Income, Race, and Other Sociodemographic Factors.” The Journal of the American Medical Association, Vol. 267, No. 1, pp. 64-69.

Stronks, D.L., J.H. Tulen , L. Pepplinkhuizen , R. Verheij , G.W. Mantel , P. Spinhoven, and J. Passchier. 1999. "Personality Traits and Psychological Reactions to Mental Stress of Female Migraine Patients.” Cephalalgia, Vol. 19, No. 6, pp. 566-574.

Verhofstadt, Elsy, Hans De Witte, and Eddy Omey. 2007. “Are Young Workers Compensated for a High Strain Job?” Working Paper, Ghent University. Available at: http://www.feb.ugent.be/soceco/sherppa/members/elsy/documents/wp_07_436.pdf

Vries, B. de, T. Freilinger, K.R.J. Vanmolkot, J. B. Koenderink, A. H. Stam, G. M. Terwindt, E. Babini, E. H. van den Boogerd, J. J.M.W. van den Heuvel, R. R. Frants, J. Haan, M. Pusch, A. M.J.M. van den Maagdenberg, M. D. Ferrari, and M. Dichgans. 2007. "Systematic Analysis of Three FHM Genes in 39 Sporadic Patients with Hemiplegic Migraine.” Neurology, Vol. 69, No. 23, pp. 2170-2176.

Waldie, Karen E., Markus Hausmann, Barry J. Milne, and Richie Poulton. 2002. "Migraine and Cognitive Function: A Life-Course Study.” Neurology, Vol. 59, No. 6, pp. 904-908.

Waldie, Karen E. and Richie Poulton. 2002. “The Burden of Illness Associated With Headache Disorders Among Young Adults in a Representative Cohort Study.” Headache: The Journal of Head and Face Pain, Vol. 42, No. 7, pp. 612-619.

Zwart, J.A., G. Dyb, K. Hagen, K.J Ødegård, A.A Dahl, G. Bovim, and L.J. Stovner. 2003. "Depression and Anxiety Disorders Associated with Headache Frequency. The Nord-Trøndelag Health Study.” European Journal of Neurology, Vol. 10, No. 2, pp. 147152. 
Table 1. Means of Selected Variables

\begin{tabular}{|c|c|c|c|}
\hline & Pooled & Males & Females \\
\hline Any Earnings & $\begin{array}{c}0.933(0.250) \\
{[12,398]}\end{array}$ & $\begin{array}{c}0.969(0.172) \\
{[5928]}\end{array}$ & $\begin{array}{c}0.899(.301) \\
{[6470]}\end{array}$ \\
\hline Hours & $\begin{array}{c}41.5(11.1) \\
{[11,501]}\end{array}$ & $\begin{array}{c}44.0(11.3) \\
{[5714]}\end{array}$ & $\begin{array}{l}39.1(10.5) \\
{[5787]}\end{array}$ \\
\hline Wages & $\begin{array}{c}18.04(21.4) \\
{[11,501]}\end{array}$ & $\begin{array}{c}19.71(24.5) \\
{[5714]}\end{array}$ & $\begin{array}{c}16.39(17.8) \\
{[5787]}\end{array}$ \\
\hline Migraine & $\begin{array}{c}0.115(0.319) \\
{[12,398]}\end{array}$ & $\begin{array}{c}0.097(0.296) \\
{[5928]}\end{array}$ & $\begin{array}{c}0.132(0.338) \\
{[6470]}\end{array}$ \\
\hline Any Earnings $=1$ & $\begin{array}{c}0.113(0.316) \\
{[11567]}\end{array}$ & $\begin{array}{c}0.097(0.295) \\
{[5748]}\end{array}$ & $\begin{array}{c}0.129(0.335) \\
{[5819]}\end{array}$ \\
\hline Any Earnings $=0$ & $\begin{array}{c}0.149(0.357) \\
{[831]}\end{array}$ & $\begin{array}{c}0.122(0.328) \\
{[180]}\end{array}$ & $\begin{array}{c}0.157(0.364) \\
{[651]}\end{array}$ \\
\hline Hours $<40$ & $\begin{array}{c}0.132(0.338) \\
{[2926]}\end{array}$ & $\begin{array}{c}0.106(0.307) \\
{[947]}\end{array}$ & $\begin{array}{c}0.144(0.351) \\
{[1979]}\end{array}$ \\
\hline Hours $\geq 40$ & $\begin{array}{c}0.110(0.313) \\
{[9333]}\end{array}$ & $\begin{array}{c}0.096(0.295) \\
{[4935]}\end{array}$ & $\begin{array}{c}0.126(0.332) \\
{[4404]}\end{array}$ \\
\hline Wages $\leq \$ 15$ & $\begin{array}{c}0.128(0.334) \\
{[5473]}\end{array}$ & $\begin{array}{c}0.113(0.316) \\
{[2460]}\end{array}$ & $\begin{array}{c}0.140(0.347) \\
{[3013]}\end{array}$ \\
\hline$\$ 15<$ Wages $\leq \$ 25$ & $\begin{array}{c}0.108(0.310) \\
{[3880]}\end{array}$ & $\begin{array}{c}0.091(0.288) \\
{[1996]}\end{array}$ & $\begin{array}{c}0.125(0.331) \\
{[1884]}\end{array}$ \\
\hline Wages $>\$ 25$ & $\begin{array}{c}0.084(0.278) \\
{[2142]}\end{array}$ & $\begin{array}{c}0.074(0.262) \\
{[1254]}\end{array}$ & $\begin{array}{c}0.098(0.297) \\
{[888]}\end{array}$ \\
\hline Migraine Diagnosis & $\begin{array}{c}0.143(0.350) \\
{[14487]}\end{array}$ & $\begin{array}{c}0.080(0.271) \\
{[6879]}\end{array}$ & $\begin{array}{c}0.200(0.400) \\
{[7608]}\end{array}$ \\
\hline Any Earnings = 1 & $\begin{array}{c}0.137(0.344) \\
{[13510]}\end{array}$ & $\begin{array}{c}0.079(0.270) \\
{[6662]}\end{array}$ & $\begin{array}{c}0.194(0.396) \\
{[6848]}\end{array}$ \\
\hline Any Earnings $=0$ & $\begin{array}{c}0.223(0.417) \\
{[977]}\end{array}$ & $\begin{array}{c}0.106(0.309) \\
\text { [217] }\end{array}$ & $\begin{array}{c}0.257(0.437) \\
{[760]}\end{array}$ \\
\hline Hours $<40$ & $\begin{array}{c}0.158(0.365) \\
{[3102]}\end{array}$ & $\begin{array}{c}0.084(0.278) \\
{[1045]}\end{array}$ & $\begin{array}{c}0.196(0.397) \\
{[2057]}\end{array}$ \\
\hline Hours $\geq 40$ & $\begin{array}{c}0.131(0.337) \\
{[10329]}\end{array}$ & $\begin{array}{c}0.077(0.267) \\
{[5577]}\end{array}$ & $\begin{array}{c}0.193(0.395) \\
{[4752]}\end{array}$ \\
\hline Wages $\leq \$ 15$ & $\begin{array}{c}0.155(0.362) \\
\text { [6369] }\end{array}$ & $\begin{array}{c}0.087(0.282) \\
{[2828]}\end{array}$ & $\begin{array}{c}0.208(0.406) \\
{[3541]}\end{array}$ \\
\hline$\$ 15<$ Wages $\leq \$ 25$ & $\begin{array}{c}0.127(0.333) \\
{[4525]}\end{array}$ & $\begin{array}{c}0.074(0.262) \\
{[2315]}\end{array}$ & $\begin{array}{c}0.182(0.386) \\
{[2210]}\end{array}$ \\
\hline Wages > \$25 & $\begin{array}{c}0.110(0.313) \\
{[2531]}\end{array}$ & $\begin{array}{c}0.069(0.254) \\
{[1475]}\end{array}$ & $\begin{array}{c}0.768(0.374) \\
{[1056]}\end{array}$ \\
\hline
\end{tabular}


Table 1 (continued). Descriptive Statistics

\begin{tabular}{cccc}
\hline & Pooled & Males & Females \\
Mother Migraine & $0.273(0.454)$ & $0.268(0.443)$ & $0.277(0.448)$ \\
& {$[11350]$} & {$[5442]$} & {$[5908]$} \\
\hline
\end{tabular}

Notes: Unweighted means are generated using data drawn from Waves I and IV of the National Longitudinal Study of Adolescent Health. Standard deviations are in parentheses and sample sizes are in brackets. 
Table 2. OLS Estimates of the Relationship between Migraine Headache and Any Earnings, Hours of Work

\begin{tabular}{|c|c|c|c|c|c|c|c|c|c|}
\hline \multicolumn{4}{|c|}{ Pooled } & \multicolumn{3}{|c|}{ Males } & \multicolumn{3}{|c|}{ Females } \\
\hline \multicolumn{10}{|c|}{ Panel I: Any Earnings } \\
\hline Migraine & $\begin{array}{c}-0.022 * * * \\
(0.008)\end{array}$ & $\begin{array}{c}-0.008 \\
(0.008)\end{array}$ & $\begin{array}{l}-0.006 \\
(0.008) \\
\end{array}$ & $\begin{array}{c}-0.009 \\
(0.008)\end{array}$ & $\begin{array}{c}-0.005 \\
(0.008)\end{array}$ & $\begin{array}{c}-0.004 \\
(0.008)\end{array}$ & $\begin{array}{c}-0.022 * \\
(0.011)\end{array}$ & $\begin{array}{c}-0.007 \\
(0.011)\end{array}$ & $\begin{array}{l}-0.005 \\
(0.011) \\
\end{array}$ \\
\hline $\mathrm{N}$ & 12,398 & 12,398 & 12,398 & 5,928 & 5,928 & 5,928 & 6,470 & 6,470 & 6,470 \\
\hline \multicolumn{10}{|c|}{ Panel II: Ln(Hours) } \\
\hline Migraine & $\begin{array}{c}-0.023^{* * *} \\
(0.008) \\
\end{array}$ & $\begin{array}{l}-0.010 \\
(0.008)\end{array}$ & $\begin{array}{l}-0.006 \\
(0.008) \\
\end{array}$ & $\begin{array}{l}-0.018 \\
(0.012) \\
\end{array}$ & $\begin{array}{l}-0.019 * \\
(0.011)\end{array}$ & $\begin{array}{l}-0.016 \\
(0.011) \\
\end{array}$ & $\begin{array}{l}-0.009 \\
(0.013) \\
\end{array}$ & $\begin{array}{c}-0.0004 \\
(0.012) \\
\end{array}$ & $\begin{array}{r}0.003 \\
(0.012) \\
\end{array}$ \\
\hline $\mathrm{N}$ & 11,501 & 11,501 & 11,501 & 5,714 & 5,714 & 5,714 & 5,787 & 5,787 & 5,787 \\
\hline $\begin{array}{l}\text { Demographic/Family } \\
\text { Controls? }\end{array}$ & No & Yes & Yes & No & Yes & Yes & No & Yes & Yes \\
\hline Education Controls? & No & No & Yes & No & No & Yes & No & No & Yes \\
\hline
\end{tabular}

***Statistically significant at the $1 \%$ level; **at the $5 \%$ level; *at the $10 \%$ level.

Notes: Each estimate is obtained from an unweighted OLS regression using data drawn the National Longitudinal Study of Adolescent Health. Demographic and family controls include controls for age, age squared, race, ethnicity, gender (for the pooled models), measured BMI, measured height, marital status, number of children, whether pregnant (for females), urbanicity, family structure during adolescence, household income in adolescence, and parental educational attainment. Education controls include PPVT score, years of schooling completed and whether currently attending school. Standard errors corrected for clustering at the school level are in parentheses. 
Table 3. OLS Estimates of Relationship between Migraine Headache and Ln(Wages)

\begin{tabular}{|c|c|c|c|c|}
\hline \multicolumn{5}{|c|}{ Panel I: Pooled Sample } \\
\hline Migraine & $\begin{array}{c}-0.118 * * * \\
(0.020)\end{array}$ & $\begin{array}{c}-0.072 * * * \\
(0.019)\end{array}$ & $\begin{array}{c}-0.057 * * * \\
(0.020)\end{array}$ & $\begin{array}{c}-0.051 * * * \\
(0.018)\end{array}$ \\
\hline $\mathrm{N}$ & 11,501 & 11,501 & 11,501 & 11,501 \\
\hline \multicolumn{5}{|c|}{ Panel II: Males } \\
\hline Migraine & $\begin{array}{c}-0.116^{* * *} \\
(0.030)\end{array}$ & $\begin{array}{c}-0.087 * * * \\
(0.031)\end{array}$ & $\begin{array}{c}-0.062 * * \\
(0.030)\end{array}$ & $\begin{array}{c}-0.064^{* *} \\
(0.029)\end{array}$ \\
\hline $\mathrm{N}$ & 5,714 & 5,714 & 5,714 & 5,714 \\
\hline \multicolumn{5}{|c|}{ Panel III: Females } \\
\hline Migraine & $\begin{array}{c}-0.100^{* * *} \\
(0.026)\end{array}$ & $\begin{array}{c}-0.056 * * \\
(0.023) \\
\end{array}$ & $\begin{array}{c}-0.049 * * \\
(0.022) \\
\end{array}$ & $\begin{array}{c}-0.042 * * \\
(0.021)\end{array}$ \\
\hline $\mathrm{N}$ & 5,787 & 5,787 & 5,787 & 5,787 \\
\hline $\begin{array}{l}\text { Demographic/Family } \\
\text { Controls? }\end{array}$ & No & Yes & Yes & Yes \\
\hline Education Controls? & No & No & Yes & Yes \\
\hline $\begin{array}{l}\text { Occupation } \\
\text { Controls? }\end{array}$ & No & No & No & Yes \\
\hline
\end{tabular}

***Statistically significant at the $1 \%$ level; **at the $5 \%$ level; *at the $10 \%$ level.

Notes: Each estimate is obtained from an unweighted OLS regression using data drawn from the National Longitudinal Study of Adolescent Health. Demographic and family controls include controls for age, age squared, race, ethnicity, gender (for the pooled sample), measured BMI, measured height, marital status, number of children, whether pregnant (for females), urbanicity, family structure during adolescence, household income in adolescence, and parental educational attainment. Education controls include PPVT score, years of schooling completed and whether currently attending school. Occupation controls include 2-digit SIC dummies for current job and job tenure. Standard errors corrected for clustering at the school level are in parentheses. 
Table 4. OLS Estimates of the Relationship between Migraine Diagnosis and Any Earnings, Hours of Work

\begin{tabular}{|c|c|c|c|c|c|c|c|c|c|}
\hline \multicolumn{4}{|c|}{ Pooled } & \multicolumn{3}{|c|}{ Males } & \multicolumn{3}{|c|}{ Females } \\
\hline \multicolumn{10}{|c|}{ Panel I: Any Earnings } \\
\hline $\begin{array}{l}\text { Migraine } \\
\text { Diagnosis }\end{array}$ & $\begin{array}{c}-0.044 * * * \\
(0.007)\end{array}$ & $\begin{array}{c}-0.022 * * * \\
(0.007)\end{array}$ & $\begin{array}{c}-0.021^{* * *} \\
(0.007)\end{array}$ & $\begin{array}{l}-0.011 \\
(0.007)\end{array}$ & $\begin{array}{l}-0.012 \\
(0.007)\end{array}$ & $\begin{array}{l}-0.010 \\
(0.008)\end{array}$ & $\begin{array}{c}-0.035^{* * *} \\
(0.009)\end{array}$ & $\begin{array}{c}-0.021^{* *} \\
(0.009)\end{array}$ & $\begin{array}{c}-0.020^{* *} \\
(0.009)\end{array}$ \\
\hline $\mathrm{N}$ & 14,487 & 14,487 & 14,487 & 6,879 & 6,879 & 6,879 & 7,608 & 7,608 & 7,608 \\
\hline \multicolumn{10}{|c|}{ Panel II: Ln(Hours) } \\
\hline $\begin{array}{l}\text { Migraine } \\
\text { Diagnosis }\end{array}$ & $\begin{array}{c}-0.029 * * * \\
(0.007) \\
\end{array}$ & $\begin{array}{c}0.001 \\
(0.007)\end{array}$ & $\begin{array}{c}0.006 \\
(0.007) \\
\end{array}$ & $\begin{array}{c}0.010 \\
(0.013) \\
\end{array}$ & $\begin{array}{c}0.004 \\
(0.013) \\
\end{array}$ & $\begin{array}{c}0.009 \\
(0.013)\end{array}$ & $\begin{array}{l}-0.003 \\
(0.009)\end{array}$ & $\begin{array}{c}0.004 \\
(0.008) \\
\end{array}$ & $\begin{array}{c}0.009 \\
(0.008)\end{array}$ \\
\hline $\mathrm{N}$ & 13,431 & 13,431 & 13,431 & 6,622 & 6,622 & 6,622 & 6,803 & 6,803 & 6,803 \\
\hline $\begin{array}{l}\text { Demographic/Family } \\
\text { Controls? }\end{array}$ & No & Yes & Yes & No & Yes & Yes & No & Yes & Yes \\
\hline Education Controls? & No & No & Yes & No & No & Yes & No & No & Yes \\
\hline
\end{tabular}

***Statistically significant at the $1 \%$ level; **at the $5 \%$ level; *at the $10 \%$ level.

Notes: Each estimate is obtained from an unweighted OLS regression using data drawn from the National Longitudinal Study of Adolescent Health. Demographic and family controls include controls for age, age squared, race, ethnicity, gender (for the pooled sample), measured BMI, measured height, marital status, number of children, whether pregnant (for females), urbanicity, family structure during adolescence, household income in adolescence, and parental educational attainment. Education controls include PPVT score, years of schooling completed and whether currently attending school. Standard errors corrected for clustering at the school level are in parentheses. 
Table 5. OLS Estimates of Relationship between Migraine Diagnosis and Ln(Wages)

\begin{tabular}{|c|c|c|c|c|}
\hline \multicolumn{5}{|c|}{ Panel I: Pooled Sample } \\
\hline $\begin{array}{l}\text { Migraine } \\
\text { Diagnosis }\end{array}$ & $\begin{array}{c}-0.107 * * * \\
(0.015)\end{array}$ & $\begin{array}{c}-0.057 * * * \\
(0.014)\end{array}$ & $\begin{array}{c}-0.047 * * * \\
(0.013)\end{array}$ & $\begin{array}{c}-0.049 * * * \\
(0.012)\end{array}$ \\
\hline $\mathrm{N}$ & 13,431 & 13,431 & 13,431 & 13,431 \\
\hline \multicolumn{5}{|c|}{ Panel II: Males } \\
\hline $\begin{array}{l}\text { Migraine } \\
\text { Diagnosis }\end{array}$ & $\begin{array}{c}-0.073 * * \\
(0.033)\end{array}$ & $\begin{array}{c}-0.051^{*} \\
(0.030)\end{array}$ & $\begin{array}{c}-0.045 \\
(0.029)\end{array}$ & $\begin{array}{c}-0.051 * \\
(0.028)\end{array}$ \\
\hline $\mathrm{N}$ & 6,622 & 6,622 & 6,622 & 6,622 \\
\hline \multicolumn{5}{|c|}{ Panel III: Females } \\
\hline $\begin{array}{l}\text { Migraine } \\
\text { Diagnosis }\end{array}$ & $\begin{array}{c}-0.078 * * * \\
(0.017) \\
\end{array}$ & $\begin{array}{c}-0.052 * * * \\
(0.017) \\
\end{array}$ & $\begin{array}{c}-0.043^{* * *} \\
(0.017) \\
\end{array}$ & $\begin{array}{c}-0.046 * * * \\
(0.017) \\
\end{array}$ \\
\hline $\mathrm{N}$ & 6,809 & 6,809 & 6,809 & 6,809 \\
\hline $\begin{array}{l}\text { Demographic/Family } \\
\text { Controls? }\end{array}$ & No & Yes & Yes & Yes \\
\hline Education Controls? & No & No & Yes & Yes \\
\hline $\begin{array}{l}\text { Occupation } \\
\text { Controls? }\end{array}$ & No & No & No & Yes \\
\hline
\end{tabular}

***Statistically significant at the $1 \%$ level; **at the $5 \%$ level; *at the $10 \%$ level.

Notes: Each estimate is obtained from an unweighted OLS regression using data drawn from the National Longitudinal Study of Adolescent Health. Demographic and family controls include controls for age, age squared, race, ethnicity, gender (for the pooled sample), measured BMI, measured height, marital status, number of children, whether pregnant (for females), urbanicity, family structure during adolescence, household income in adolescence, and parental educational attainment. Education controls include PPVT score, years of schooling completed and whether currently attending school. Occupation controls include 2-digit SIC dummies for current job and job tenure. Standard errors corrected for clustering at the school level are in parentheses. 
Table 6. Sensitivity of OLS Estimates of the Relationship between Migraine Headache and Labor Market Outcomes to Controlling for School and Grade Fixed Effects, Mental Health, Sleep Deprivation, Drunkenness, and Hypertension

\begin{tabular}{|c|c|c|c|c|c|c|c|c|c|}
\hline & \multicolumn{3}{|c|}{ Pooled } & \multicolumn{3}{|c|}{ Males } & \multicolumn{3}{|c|}{ Females } \\
\hline $\mathrm{N}$ & 12,398 & 12,398 & 12,398 & 5,928 & 5,928 & 5,928 & 6,470 & 6,470 & 6,470 \\
\hline $\mathrm{N}$ & 11,501 & 11,501 & 11,501 & 5,714 & 5,714 & 5,714 & 5,787 & 5,787 & 5,787 \\
\hline & \multicolumn{9}{|c|}{ Panel III: Ln( Wages) } \\
\hline Migraine & $\begin{array}{c}-0.051 * * * \\
(0.018)\end{array}$ & $\begin{array}{c}-0.047^{* * *} \\
(0.018)\end{array}$ & $\begin{array}{c}-0.047 * * * \\
(0.018)\end{array}$ & $\begin{array}{c}-0.064^{* *} \\
(0.029)\end{array}$ & $\begin{array}{c}-0.060^{* *} \\
(0.029)\end{array}$ & $\begin{array}{l}-0.057 * \\
(0.029)\end{array}$ & $\begin{array}{c}-0.042^{* *} \\
(0.021)\end{array}$ & $\begin{array}{c}-0.037 * \\
(0.020)\end{array}$ & $\begin{array}{l}-0.039 * \\
(0.020)\end{array}$ \\
\hline $\begin{array}{l}\text { CES-D, RSE } \\
\text { Sleep, Drunk, } \\
\text { Hypertension }\end{array}$ & No & No & Yes & No & No & Yes & No & No & Yes \\
\hline
\end{tabular}

***Statistically significant at the $1 \%$ level; **at the $5 \%$ level; *at the $10 \%$ level.

Notes: Each estimate is obtained from an unweighted OLS regression using data drawn from the National Longitudinal Study of Adolescent Health. All models include controls for age, age squared, race, ethnicity, gender (for the pooled models), measured BMI, measured height, marital status, number of children, whether pregnant (for females), urbanicity, family structure during adolescence, household income in adolescence, and parental educational attainment, PPVT score, years of schooling completed, and whether currently attending school. Wage models also include controls for occupation and job tenure. Standard errors corrected for clustering at the school level are in parentheses. 
Table 7. Sensitivity of OLS Estimates of the Relationship Between Migraine Headache and Labor Market Outcomes to Controlling for Neuroticism and Anxiety Scores

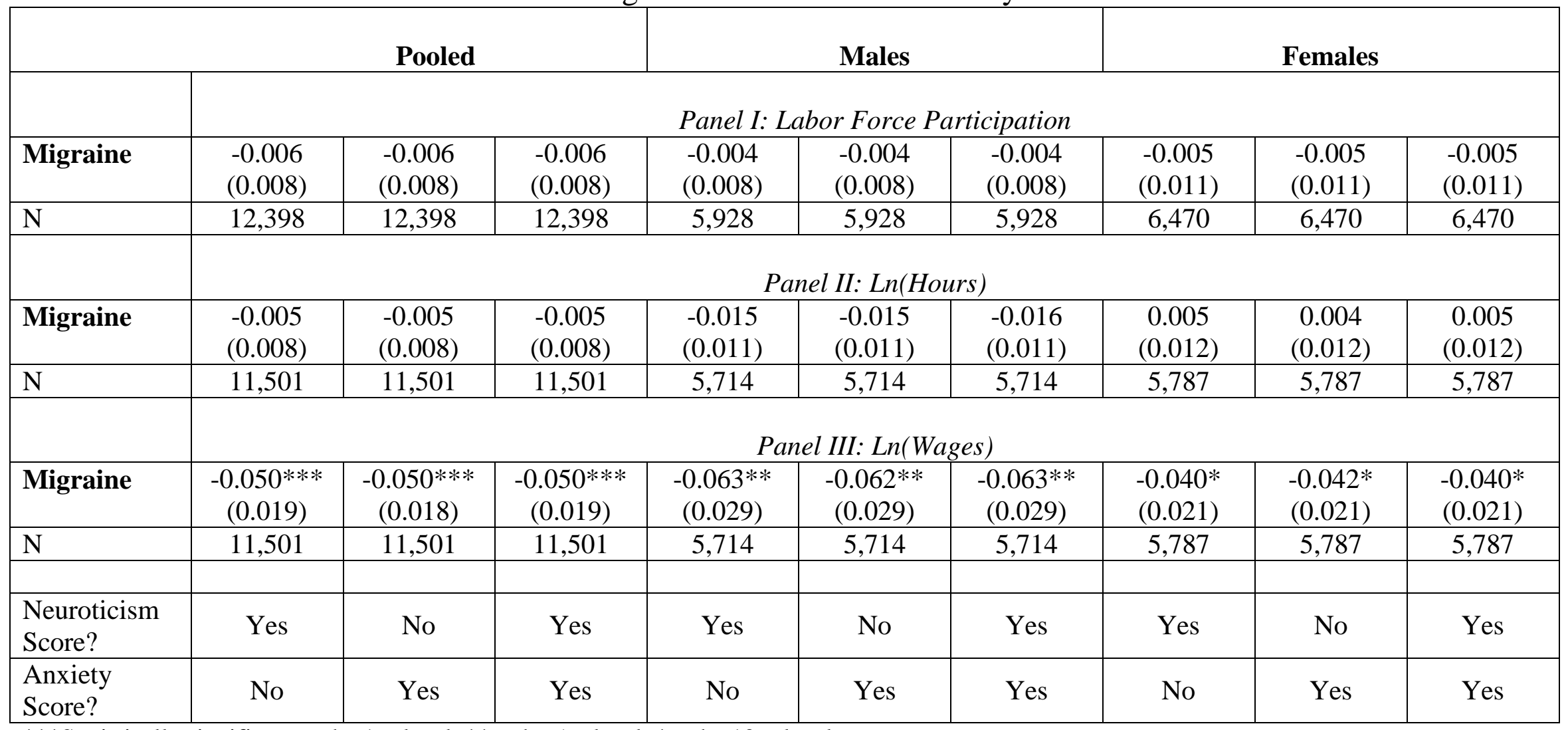

*** Statistically significant at the $1 \%$ level; **at the $5 \%$ level; *at the $10 \%$ level.

Notes: Each estimate is obtained from an unweighted OLS regression using data drawn from the National Longitudinal Study of Adolescent Health. All models include controls for age, age squared, race, ethnicity, gender (for the pooled sample), measured BMI, measured height, marital status, number of children, whether pregnant (for females), urbanicity, family structure during adolescence, household income in adolescence, and parental educational attainment, PPVT score, years of schooling completed, and whether currently attending school. Wage models include additional controls for occupation and job tenure. Standard errors corrected for clustering at the school level are in parentheses. 
Table 8. First-Stage Estimates of Relationship between Mother’s Migraine Status and the Whether the Respondent was Diagnosed with Migraines by a Health Professional

\begin{tabular}{|l|c|c|c|c|c|c|}
\hline \multicolumn{2}{|c|}{ Pooled } & \multicolumn{2}{c|}{ Males } & \multicolumn{2}{c|}{ Females } \\
\hline Mother Migraine & $\begin{array}{l}0.069 * * * \\
(0.009)\end{array}$ & $\begin{array}{c}0.070^{* * *} \\
(0.010)\end{array}$ & $\begin{array}{l}0.048^{* * *} \\
(0.010)\end{array}$ & $\begin{array}{l}0.047 * * * \\
(0.011)\end{array}$ & $\begin{array}{l}0.085^{* * *} \\
(0.014) \\
(0.015)\end{array}$ \\
\hline First-stage F-stat & 57.0 & 53.0 & 22.3 & 20.0 & 36.2 & 35.0 \\
\hline $\mathrm{N}$ & 11929 & 11069 & 5696 & 5486 & 6283 \\
\hline $\begin{array}{l}\text { LFP Sample } \\
\text { Sample }\end{array}$ & Yes & No & Yes & No & Yes \\
\hline
\end{tabular}

$* * *$ Statistically significant at the $1 \%$ level; **at the $5 \%$ level; *at the $10 \%$ level.

Notes: Each estimate is obtained from an unweighted regression using data drawn from the National Longitudinal Study of Adolescent Health. All models include controls for age, age squared, race, ethnicity, gender (for the pooled sample), measured BMI, measured height, marital status, number of children, whether pregnant (for females), urbanicity, family structure during adolescence, household income in adolescence, and parental educational attainment, PPVT score, years of schooling completed, and whether currently attending school. 
Table 9. 2SLS Estimates of the Relationship between Migraine Diagnosis and Labor Market Outcomes

\begin{tabular}{|c|c|c|c|c|c|c|}
\hline & \multicolumn{2}{|c|}{ Pooled } & \multicolumn{2}{|c|}{ Males } & \multicolumn{2}{|c|}{ Females } \\
\hline & \multicolumn{6}{|c|}{ Panel I: Labor Force Participation } \\
\hline Migraine Diagnosis & $\begin{array}{c}-0.090 \\
(0.070)\end{array}$ & $\begin{array}{c}-0.091 \\
(0.075)\end{array}$ & $\begin{array}{c}-0.070 \\
(0.116)\end{array}$ & $\begin{array}{c}-0.072 \\
(0.124)\end{array}$ & $\begin{array}{c}-0.092 \\
(0.087)\end{array}$ & $\begin{array}{c}-0.086 \\
(0.092)\end{array}$ \\
\hline First-Stage F-stat & 57.0 & 54.0 & 22.3 & 19.3 & 26.2 & 35.6 \\
\hline $\mathrm{N}$ & 11929 & 11929 & 5696 & 5696 & 6233 & 6233 \\
\hline & \multicolumn{6}{|c|}{ Panel II: Ln(Hours) } \\
\hline Migraine Diagnosis & $\begin{array}{l}-0.019 \\
(0.099)\end{array}$ & $\begin{array}{c}0.007 \\
(0.102) \\
\end{array}$ & $\begin{array}{l}-0.129 \\
(0.200)\end{array}$ & $\begin{array}{l}-0.089 \\
(0.241)\end{array}$ & $\begin{array}{c}0.036 \\
(0.095)\end{array}$ & $\begin{array}{c}0.044 \\
(0.093)\end{array}$ \\
\hline First-stage F-stat & 53.9 & 52.1 & 20.7 & 18.2 & 33.7 & 33.7 \\
\hline $\mathrm{N}$ & 11069 & 11069 & 5486 & 5486 & 5583 & 5583 \\
\hline & \multicolumn{6}{|c|}{ Panel III: Ln(Wages) } \\
\hline Migraine Diagnosis & $\begin{array}{c}-0.324^{*} \\
(0.169)\end{array}$ & $\begin{array}{c}-0.309^{*} \\
(0.177)\end{array}$ & $\begin{array}{c}-0.358 \\
(0.362)\end{array}$ & $\begin{array}{c}-0.330 \\
(0.396)\end{array}$ & $\begin{array}{c}-0.315^{*} \\
(0.181)\end{array}$ & $\begin{array}{c}-0.299 * \\
(0.178)\end{array}$ \\
\hline First-stage F-stat & 53.0 & 51.1 & 20.0 & 17.5 & 35.0 & 34.9 \\
\hline $\mathrm{N}$ & 11069 & 11069 & 5486 & 5486 & 5583 & 5583 \\
\hline $\begin{array}{l}\text { Parental Involvement } \\
\text { and Health Controls? }\end{array}$ & No & Yes & No & Yes & No & Yes \\
\hline
\end{tabular}

***Statistically significant at the $1 \%$ level; **at the $5 \%$ level; *at the $10 \%$ level.

Notes: Each estimate is obtained from an unweighted 2SLS regression using data drawn the National Longitudinal Study of Adolescent Health. All models include controls for age, age squared, race, ethnicity, gender (for the pooled sample), measured BMI, measured height, marital status, number of children, whether pregnant (for females), urbanicity, family structure during adolescence, household income in adolescence, and parental educational attainment, PPVT score, years of schooling completed, and whether currently attending school. Wage models include additional controls for occupation and job tenure. Standard errors corrected for clustering at the school are in parentheses. 
Appendix Table 1. Sensitivity of OLS Estimates of the Relationship between Migraine Diagnosis and Labor Market Outcomes to Controls for School and Grade Fixed Effects, Mental Health, Sleep Deprivation, Drunkenness, and Hypertension

\begin{tabular}{|c|c|c|c|c|c|c|c|c|c|}
\hline & \multicolumn{3}{|c|}{ Pooled } & \multicolumn{3}{|c|}{ Males } & \multicolumn{3}{|c|}{ Females } \\
\hline \multicolumn{10}{|c|}{ Panel I: Labor Force Participation } \\
\hline $\mathrm{N}$ & 14487 & 14487 & 14487 & 6897 & 6897 & 6897 & 7608 & 7608 & 7608 \\
\hline \multicolumn{10}{|c|}{ Panel II: Ln( Hours) } \\
\hline $\begin{array}{l}\text { Migraine } \\
\text { Diagnosis }\end{array}$ & $\begin{array}{c}0.006 \\
(0.007)\end{array}$ & $\begin{array}{c}0.005 \\
(0.007)\end{array}$ & $\begin{array}{c}0.006 \\
(0.007)\end{array}$ & $\begin{array}{c}0.009 \\
(0.013)\end{array}$ & $\begin{array}{c}0.008 \\
(0.013)\end{array}$ & $\begin{array}{c}0.009 \\
(0.013)\end{array}$ & $\begin{array}{c}0.009 \\
(0.008)\end{array}$ & $\begin{array}{c}0.009 \\
(0.008)\end{array}$ & $\begin{array}{c}0.010 \\
(0.009)\end{array}$ \\
\hline $\mathrm{N}$ & 13431 & 13431 & 13431 & 6622 & 6622 & 6622 & 6809 & 6809 & 6809 \\
\hline $\begin{array}{l}\text { School Fixed } \\
\text { Effects? }\end{array}$ & No & Yes & Yes & No & Yes & Yes & No & Yes & Yes \\
\hline $\begin{array}{l}\text { CES-D, RSE, } \\
\text { Sleep, Drunk, } \\
\text { Hypertension }\end{array}$ & No & No & Yes & No & No & Yes & No & No & Yes \\
\hline
\end{tabular}

***Statistically significant at the $1 \%$ level; **at the $5 \%$ level; *at the $10 \%$ level.

Notes: Each estimate is obtained from an unweighted OLS regression using data drawn from the National Longitudinal Study of Adolescent Health. All models include controls for age, age squared, race, ethnicity, gender (for the pooled sample), measured BMI, measured height, marital status, number of children, whether pregnant (for females), urbanicity, family structure during adolescence, household income in adolescence, and parental educational attainment, PPVT score, years of schooling completed, and whether currently attending school. Wage models include additional controls for occupation and job tenure. Standard errors corrected for clustering at the school level are in parentheses. 
Appendix Table 2. Sensitivity of OLS Estimates of the Relationship between Migraine Diagnosis and Labor Market Outcomes to Controlling for Neuroticism and Anxiety Scores

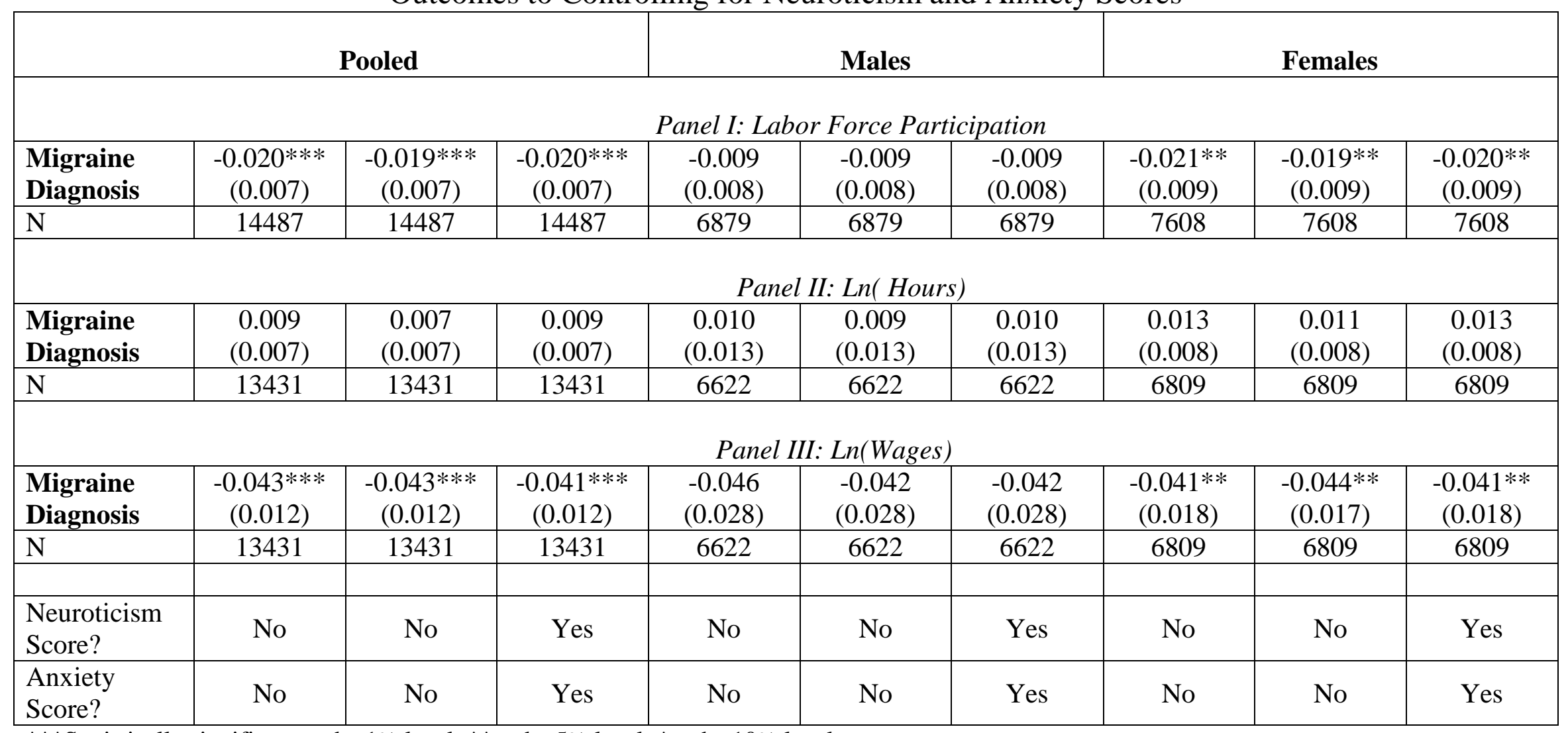

***Statistically significant at the $1 \%$ level; **at the $5 \%$ level; *at the $10 \%$ level.

Notes: Each estimate is obtained from an unweighted OLS regression using data drawn from the National Longitudinal Study of Adolescent Health. All models include controls for age, age squared, race, ethnicity, gender (for the pooled sample), measured BMI, measured height, marital status, number of children, whether pregnant (for females), urbanicity, family structure during adolescence, household income in adolescence, and parental educational attainment, PPVT score, years of schooling completed, and whether currently attending school. Wage models include additional controls for occupation and job tenure. Standard errors corrected for clustering at the school level are in parentheses. 